\title{
Family-Based Genetic Association for Molar-Incisor Hypomineralization
}

\author{
Fabiano Jeremias $^{a}$ Ricardo A.G. Pierri ${ }^{a}$ Juliana F. Souza ${ }^{c}$ \\ Camila Maria B. Fragelli ${ }^{a}$ Manuel Restrepo ${ }^{a}$ Livia S. Finoti $^{b}$ \\ Diego G. Bussanelia Rita C.L. Cordeiro ${ }^{a}$ Rodrigo Secolin ${ }^{d}$ \\ Claudia V. Maurer-Morellid Raquel M. Scarel-Caminaga ${ }^{b}$ \\ Lourdes Santos-Pinto ${ }^{a}$
}

Departments of a Orthodontics and Pediatric Dentistry and ${ }^{b}$ Morphology, Araraquara School of Dentistry, Universidade Estadual Paulista - UNESP, Araraquara, ' ${ }^{\circ}$ Discipline of Paediatric Dentistry, Department of Stomatology, School of Dentistry, Federal University of Paraná - UFPR, Paraná, and ' Department of Medical Genetics, School of Medical Sciences, University of Campinas - UNICAMP, Campinas, Brazil

\section{Key Words}

Genetic association study · Genetic polymorphisms · Tooth hypomineralization

\footnotetext{
Abstract

Despite some evidence of genetic and environmental factors on molar-incisor hypomineralization ( $\mathrm{MIH})$, its aetiology remains unclear. This family-based genetic association study aimed more comprehensively to investigate the genetic carriage potentially involved in $\mathrm{MIH}$ development. DNA was obtained from buccal cells of 391 individuals who were birth family members of 101 Brazilian nuclear families. Sixty-three single nucleotide polymorphisms (SNPs) were investigated in 21 candidate genes related to amelogenesis using the TaqMan $^{\mathrm{TM}}$ OpenArray ${ }^{\mathrm{TM}}$ Genotyping platform. All SNPs were genotyped in 165 birth family members unaffected by $\mathrm{MIH}$, 96 with unknown MIH status and 130 affected individuals (50.7\% with severe $\mathrm{MIH}$ ). Association analysis was performed by the transmission/disequilibrium test (TDT), and statistical
}

results were corrected using the false discovery rate. Significant results were obtained for SNPs rs7821494 (FAM83H gene, $\mathrm{OR}=3.7 ; 95 \% \mathrm{Cl}=1.75-7.78)$, rs34367704 (AMBN gene, $\mathrm{OR}=2.7 ; 95 \% \mathrm{Cl}=1.16-6.58)$, rs3789334 (BMP2 gene, $\mathrm{OR}=$ 2.9; $95 \% \mathrm{Cl}=1.34-6.35)$, rs6099486 (BMP7 gene, $\mathrm{OR}=2.2$; $95 \% \mathrm{Cl}=1.14-4.38)$, rs762642 (BMP4 gene, OR $=2.3 ; 95 \%$ $\mathrm{Cl}=1.38-3.65)$, rs7664896 (ENAM gene, $\mathrm{OR}=2.1 ; 95 \% \mathrm{Cl}=$ 1.19-3.51), rs1711399 (MMP20 gene, $\mathrm{OR}=0.4 ; 95 \% \mathrm{Cl}=0.20$ 0.72 ), rs1711423 (MMP20 gene, $\mathrm{OR}=2.1 ; 95 \% \mathrm{Cl}=1.18-3.61$ ), rs2278163 ( $D L X 3$ gene, $\mathrm{OR}=2.8 ; 95 \% \mathrm{Cl}=1.26-6.41)$, rs6996321 (FGFR1 gene, $\mathrm{OR}=2.7 ; 95 \% \mathrm{Cl}=1.20-5.88$ ), and rs5979395 (AMELX gene, $\mathrm{OR}=11.7 ; 95 \% \mathrm{Cl}=1.63-84.74$ ). Through this family-based association study, we concluded that variations in genes related to amelogenesis were associated with the susceptibility to develop MIH. This result is in agreement with the multifactorial idea of the MIH aetiology, but further studies are necessary to investigate more thoroughly the factors that could influence $\mathrm{MIH}$.

(c) 2016 S. Karger AG, Basel

\section{KARGER}

E-Mail karger@karger.com www.karger.com/cre
Lourdes Santos-Pinto

Araraquara School of Dentistry, UNESP

Rua Humaita, 1680

Araraquara, SP 14801-903 (Brazil)

E-Mail lspinto@foar.unesp.br 
The process of tooth formation originates from the interaction between the oral epithelium and the ectomesenchyme through a series of temporary and highly regulated events. This results in the differentiation of epithelial cells into ameloblasts, a process referred to as amelogenesis, which is a phase of enamel development. This process is very sensitive and includes developing a specific extracellular matrix, matrix processing, and controlling the microenvironment of the developing enamel tissue [He et al., 2010; Lacruz et al., 2012]. The genetic control of dental development represents a complex series of events, and occasional mutations in the genes coding enamel proteins may cause alterations that affect the molecular pathways. The consequence is the occurrence of a deficiency in the amount of enamel (hypoplasia), a change in the composition (hypomineralization), or a change in the enamel structure [Wright et al., 2015]. Therefore, amelogenesis is under strict genetic control, and even caries susceptibility can be affected by genetic variation [Simmer and Hu, 2001; Deeley et al., 2008; Vieira et al., 2008; Shimizu et al., 2012].

In the last several years, a particular pattern of hypomineralization that affects molars and incisors has gained importance. Molar-incisor hypomineralization ( $\mathrm{MIH}$ ) refers to demarcated, qualitative enamel defects of systemic origin, affecting one or more permanent molars with or without involvement of the incisor teeth [Weerheijm et al., 2001]. A recent literature review found 52 studies demonstrating a wide variation in the prevalence of MIH (2.9-44 \%) [Elfrink et al., 2015]. In Brazil, there are data on the prevalence of $12.3 \%$ [Jeremias et al., 2013a] and $19.8 \%$ [da Costa-Silva et al., 2010] for different regions. One of the main characteristics of teeth affected by $\mathrm{MIH}$ is the greater porosity of the enamel, which can easily be fractured due to masticatory forces, leading to exposed dentin that may promote the development of caries. Therefore, MIH is associated with caries [Muratbegovic et al., 2007; Cho et al., 2008; Alaluusua, 2010].

In clinical practice, we have frequently observed patients affected by MIH and also their parents and siblings. However, the aetiology of MIH remains unclear [Alaluusua, 2010; Sönmez et al., 2013; Wuollet et al., 2014]. There are studies demonstrating a potential environmental contribution to MIH [Jan et al., 2007; Alaluusua, 2010; Souza et al., 2012; Loli et al., 2015; Oyedele et al., 2015] and other studies demonstrating evidence of the genetic influence on the occurrence of MIH [Jeremias et al., 2013b; Kühnisch et al., 2014]. Kuscu et al. [2013] mentioned that $\mathrm{MIH}$ is a multifactorial disturbance, but the specific environmental factors and the genetic contribution are still not completely understood. Therefore, we evaluated the presence of genetic association in 63 single nucleotide polymorphisms (SNPs) of 21 candidate genes related to amelogenesis in Brazilian nuclear families affected by MIH using a family-based genetic association approach.

\section{Materials and Methods}

\section{Subject Screening and Sample Collection}

A total of 101 eligible nuclear families were enrolled from the Pedodontics Clinics of São Paulo State University and from day care facilities in Araraquara, Brazil. All birth family members ( $\mathrm{n}=$ 391 individuals) enrolled in this study gave their informed consent/assent to participate in this study, which was approved by the Research Ethics Committee of the FOAr-UNESP (protocol No. $45 / 10$ ) according to the guidelines of the Declaration of Helsinki.

The exclusion criteria included having evidence of enamel formation linked to a condition such as amelogenesis imperfecta or dental fluorosis or to the use of a fixed appliance. Calibrated examiners (two paediatric dentists/researchers) carried out the clinical examination in all birth family members to investigate enamel defects and dental caries. Clinical examinations were performed with the use of a flashlight and a mouth mirror. Gauze was used to dry and clean the teeth prior to examination (researcher L.S.-P. was the calibrator for F.J. and C.M.B.F). Examination calibrations were performed according to the following protocol. First, the calibrator presented the examiners with the criteria for $\mathrm{MIH}$ detection, showed pictures of several situations that would be observed during the examination, and discussed each of these situations in a session that lasted 1-2 h. Next, the calibrator and examiners examined 1020 subjects and discussed each case. The intra-examiner agreement was assessed by a second clinical examination in $10 \%$ of the sample after 2 weeks, with a kappa of 1.0. The MIH phenotype (enamel opacity, enamel breakdown, and atypical restoration) was based on clinical findings defined by the criteria of the European Academy of Paediatric Dentistry (EAPD) [Weerheijm et al., 2003].

Buccal epithelial cells from the subjects were obtained using $3 \mathrm{ml}$ of $3 \%$ glucose mouthwash for $2 \mathrm{~min}$. DNA was extracted utilizing the PureLink Genomic DNA Mini Kit (Invitrogen ${ }^{\mathrm{TM}}$, Carlsbad, Calif., USA) according to the manufacturer's instructions. The purity and concentration of the samples were checked using a NanoVue ${ }^{\mathrm{TM}}$ Spectrophotometer (GE Healthcare, Little Chalfont, UK).

\section{Genotyping}

We used the SNP Browser 4.0 software (Applied Biosystems, Foster City, Calif., USA) to select the 63 SNPs among 21 genes involved in enamel formation (table 1). The SNPs were genotyped using the TaqMan ${ }^{\circledR}$ OpenArray ${ }^{\mathrm{TM}}$ Genotyping System and the TaqMan $^{\mathrm{TM}}$ Genotyper software version 1.0.1. (Applied Biosystems). The quality value of a data point's genotype was determined by a threshold above 0.95 .

\section{Statistical Analysis}

Genotyped data and minor allele frequency (minimum allele frequency) of the SNPs were estimated by the JINGLEFIX program [Secolin et al., 2008]. Mendelian inconsistencies were evaluated by 
Table 1. Genes analysed according to markers and alleles

\begin{tabular}{|c|c|c|c|c|c|}
\hline Gene & $\mathrm{SNP}(\mathrm{rs})$ & Allele & Gene & SNP (rs) & Allele \\
\hline MMP20 & 2280211 & $\mathrm{CT}$ & Amelotin & 17676820 & CT \\
\hline MMP20 & 1784410 & GT & Amelotin & 13151614 & CG \\
\hline MMP20 & 1711399 & $\mathrm{AC}$ & Amelotin & 17149007 & CT \\
\hline MMP20 & 1711441 & $\mathrm{AC}$ & Distal-less 3 homeobox & 2278163 & CT \\
\hline MMP20 & 1784438 & $\mathrm{AG}$ & Distal-less 3 homeobox & 3891034 & $\mathrm{AG}$ \\
\hline MMP20 & 1711422 & AG & Kallikrein & 2235091 & CT \\
\hline MMP20 & 1784441 & $\mathrm{CT}$ & Bone morphogenetic protein- 2 & 3789334 & $\mathrm{AG}$ \\
\hline MMP20 & 1784440 & AG & Bone morphogenetic protein-2 & 235767 & GT \\
\hline MMP20 & 1711423 & $\mathrm{AC}$ & Bone morphogenetic protein-2 & 15705 & AG \\
\hline Tuftelin & 4970956 & $\mathrm{AG}$ & Bone morphogenetic protein-2 & 1005464 & $\mathrm{AG}$ \\
\hline Tuftelin & 7526319 & $\mathrm{CT}$ & Bone morphogenetic protein- 4 & 17563 & CT \\
\hline Tuftelin & 11204848 & CT & Bone morphogenetic protein- 4 & 762642 & GT \\
\hline Dentin sialophosphoprotein & 2615487 & CT & Bone morphogenetic protein-7 & 230191 & $\mathrm{CT}$ \\
\hline Dentin sialophosphoprotein & 3750025 & CT & Metallopeptidase inhibitor 2 & 2376999 & CT \\
\hline Dentin sialophosphoprotein & 2615489 & $\mathrm{AG}$ & Metallopeptidase inhibitor 2 & 7218729 & CG \\
\hline Amelogenin & 6530435 & $\mathrm{AG}$ & Fibroblast growth factor receptor 1 & 6987534 & CG \\
\hline Amelogenin & 6654939 & $\mathrm{CT}$ & Fibroblast growth factor receptor 1 & 6996321 & AG \\
\hline Amelogenin & 5979395 & AG & Fibroblast growth factor receptor 2 & 4752566 & GT \\
\hline Amelogenin & 946252 & $\mathrm{AG}$ & Fibroblast growth factor receptor 2 & 2981427 & $\mathrm{AG}$ \\
\hline Amelogenin & 5934996 & $\mathrm{AT}$ & Fibroblast growth factor receptor 2 & 1078806 & CT \\
\hline Amelogenin & 17878486 & CT & Fibroblast growth factor 1 & 34010 & $\mathrm{AC}$ \\
\hline Enamelin & 2609426 & AG & Fibroblast growth factor 2 & 1048201 & CT \\
\hline Enamelin & 7664896 & CG & Parathyroid hormone & 307253 & CT \\
\hline Enamelin & 1055660 & CT & Parathyroid hormone receptor 1 & 7652849 & CT \\
\hline
\end{tabular}

PEDCHECK software [O'Connell and Weeks, 1998]. The HardyWeinberg equilibrium and the degree of linkage disequilibrium between SNPs were evaluated by the HAPLOVIEW program [Barrett et al., 2005].

Family-based association analysis was performed by the transmission/disequilibrium test (TDT) using the UNPHASED program [Dudbridge, 2008], and statistical results were adjusted for multiple testing using the false discovery rate. The statistical power $(1-\beta)$ of the sample was evaluated using the TDT power calculator 1.2.1 [Chen and Deng, 2001], including the following parameters: $1-\beta>0.8$, corrected type I error $=0.05$, and prevalence $=$ $12.3 \%$ [Jeremias et al., 2013a].

\section{Results}

There were $79(78.2 \%)$ nuclear families with only 1 MIH-affected individual and $22(21.8 \%)$ with 2 or more $\mathrm{MIH}$-affected individuals, including siblings and parents
Table 2. Proportion of affected individuals per nuclear family

\begin{tabular}{lc}
\hline $\begin{array}{l}\text { MIH-affected individuals } \\
\text { per family, } \mathrm{n}\end{array}$ & Nuclear families, $\mathrm{n}(\%)$ \\
\hline 1 & $79(78.2)$ \\
2 & $17(16.8)$ \\
3 & $3(3.0)$ \\
4 & $2(2.0)$ \\
\hline Total & 101 \\
\hline
\end{tabular}

(table 2). In total, there were 165 birth family members unaffected by MIH, 96 with unknown MIH status and $130 \mathrm{MIH}$-affected individuals. Of the individuals evaluated, $49.6 \%$ were male (mean age 10 years; DMFT $=1.8$ ). Among the affected individuals $(n=130), 50.7 \%$ were 
Table 3. TDT analysis of the SNPs in MIH families

\begin{tabular}{|c|c|c|c|c|c|c|c|}
\hline SNP (rs) & $\begin{array}{l}\text { Informative } \\
\text { trios, } \mathrm{n}\end{array}$ & $\begin{array}{l}\text { Mendelian } \\
\text { errors, } \mathrm{n}\end{array}$ & $\begin{array}{l}\text { Minor allele } \\
\text { frequency }\end{array}$ & Alleles & $\begin{array}{l}\text { Hardy-Wein- } \\
\text { berg p value }\end{array}$ & $\begin{array}{l}\text { TDT } \\
\text { p value }\end{array}$ & $\begin{array}{l}\text { FDR-corrected } \\
\mathrm{p} \text { values }\end{array}$ \\
\hline 3790506 & 48 & 0 & 0.279 & $\mathrm{~T}: \mathrm{C}$ & 0.099 & 0.6168 & 0.7771 \\
\hline 4970956 & 48 & 0 & 0.268 & G:A & 0.372 & 0.0185 & 0.0685 \\
\hline 7526319 & 48 & 0 & 0.406 & $\mathrm{~T}: \mathrm{C}$ & 0.091 & 0.1099 & 0.2387 \\
\hline 11204848 & 47 & 0 & 0.372 & $\mathrm{~T}: \mathrm{C}$ & 0.087 & 0.9093 & 0.9709 \\
\hline 198968 & 48 & 0 & 0.191 & G:A & 1.000 & 0.8788 & 0.9709 \\
\hline 2235091 & 48 & 0 & 0.312 & $\mathrm{~T}: \mathrm{C}$ & 0.132 & 0.7097 & 0.8279 \\
\hline 7821494 & 47 & 0 & 0.392 & C:G & 0.467 & 0.0000 & 0.0000 \\
\hline 12681370 & 48 & 0 & 0.275 & $\mathrm{G}: \mathrm{A}$ & 0.885 & 0.4101 & 0.6151 \\
\hline 7463064 & 46 & 0 & 0.339 & $\mathrm{~T}: \mathrm{C}$ & 0.053 & 1.0000 & 1.0000 \\
\hline 34367704 & 48 & 0 & 0.138 & G:A & 0.389 & 0.0102 & 0.0457 \\
\hline 4694075 & 48 & 0 & 0.422 & $\mathrm{~T}: \mathrm{C}$ & 0.000 & 0.1016 & 0.2387 \\
\hline 15705 & 47 & 0 & 0.460 & G:A & 0.009 & 0.0000 & 0.0000 \\
\hline 235767 & 46 & 0 & 0.345 & $\mathrm{~T}: \mathrm{G}$ & 1.000 & 0.0823 & 0.2257 \\
\hline 3789334 & 47 & 0 & 0.198 & $\mathrm{G}: \mathrm{A}$ & 0.526 & 0.0016 & 0.0144 \\
\hline 1005464 & 46 & 0 & 0.061 & $\mathrm{G}: \mathrm{A}$ & 1.000 & 0.5257 & 0.7199 \\
\hline 927836 & 46 & 0 & 0.095 & $\mathrm{~T}: \mathrm{C}$ & 1.000 & 0.8083 & 0.9093 \\
\hline 230191 & 45 & 0 & 0.345 & $\mathrm{~T}: \mathrm{C}$ & 0.067 & 0.2618 & 0.4340 \\
\hline 12479955 & 44 & 0 & 0.140 & $\mathrm{G}: \mathrm{A}$ & 1.000 & 0.1090 & 0.2387 \\
\hline 6099486 & 48 & 0 & 0.181 & $\mathrm{~T}: \mathrm{C}$ & 0.476 & 0.0109 & 0.0457 \\
\hline 17563 & 48 & 0 & 0.460 & $\mathrm{~T}: \mathrm{C}$ & 0.538 & 0.4726 & 0.6616 \\
\hline 762642 & 47 & 0 & 0.356 & G:T & 0.058 & 0.0006 & 0.0075 \\
\hline 2071047 & 48 & 0 & 0.379 & $\mathrm{~T}: \mathrm{C}$ & 0.675 & 0.6615 & 0.8171 \\
\hline 1055660 & 47 & 0 & 0.013 & $\mathrm{~T}: \mathrm{C}$ & 1.000 & 1.0000 & 1.0000 \\
\hline 7664896 & 47 & 0 & 0.490 & G:C & 0.534 & 0.0058 & 0.0332 \\
\hline 2609426 & 48 & 0 & 0.279 & A:G & 0.003 & 0.4726 & 0.6616 \\
\hline 1784410 & 46 & 0 & 0.297 & $\mathrm{~T}: \mathrm{G}$ & 0.860 & 0.2227 & 0.3897 \\
\hline 1711399 & 47 & 0 & 0.312 & $\mathrm{C}: \mathrm{A}$ & 1.000 & 0.0013 & 0.0136 \\
\hline 1711441 & 48 & 0 & 0.356 & C:A & 0.058 & 0.0918 & 0.2387 \\
\hline 1784441 & 48 & 0 & 0.131 & $\mathrm{~T}: \mathrm{C}$ & 0.494 & 0.0824 & 0.2257 \\
\hline 1784440 & 48 & 0 & 0.319 & G:A & 0.179 & 0.1361 & 0.2858 \\
\hline 1784423 & 47 & 0 & 0.399 & $\mathrm{~T}: \mathrm{C}$ & 0.006 & 0.0124 & 0.0488 \\
\hline 1711422 & 48 & 0 & 0.379 & $\mathrm{G}: \mathrm{A}$ & 0.530 & 0.2160 & 0.3897 \\
\hline 2280211 & 47 & 0 & 0.331 & $\mathrm{~T}: \mathrm{C}$ & 0.880 & 0.0232 & 0.0812 \\
\hline 1784438 & 47 & 0 & 0.226 & G:A & 0.149 & 0.3253 & 0.5254 \\
\hline 1711423 & 48 & 0 & 0.383 & C:A & 0.268 & 0.0069 & 0.0344 \\
\hline 34010 & 45 & 0 & 0.003 & C:A & 1.000 & 1.0000 & 1.0000 \\
\hline 1078806 & 47 & 0 & 0.476 & $\mathrm{~T}: \mathrm{C}$ & 0.609 & 0.3605 & 0.5677 \\
\hline 2981427 & 47 & 0 & 0.419 & $\mathrm{G}: \mathrm{A}$ & 0.025 & 0.1063 & 0.2387 \\
\hline 4752566 & 48 & 0 & 0.436 & G:T & 0.362 & 0.5468 & 0.7329 \\
\hline 2278163 & 47 & 0 & 0.213 & $\mathrm{~T}: \mathrm{C}$ & 0.162 & 0.0036 & 0.0252 \\
\hline 3891034 & 48 & 0 & 0.477 & G:A & 0.166 & 0.7008 & 0.8279 \\
\hline 11568785 & 46 & 0 & 0.133 & G:A & 0.962 & 0.2187 & 0.3897 \\
\hline 1048201 & 47 & 0 & 0.372 & $\mathrm{C}: \mathrm{T}$ & 0.153 & 0.1633 & 0.3215 \\
\hline 6442307 & 47 & 0 & 0.423 & $\mathrm{~A}: \mathrm{C}$ & 0.002 & 0.7388 & 0.8462 \\
\hline 7652849 & 48 & 0 & 0.493 & $\mathrm{~T}: \mathrm{C}$ & 0.836 & 0.5927 & 0.7620 \\
\hline 4803455 & 47 & 0 & 0.269 & $\mathrm{C}: \mathrm{A}$ & 0.008 & 0.1001 & 0.2387 \\
\hline 6987534 & 46 & 0 & 0.361 & G:C & 0.001 & 0.2014 & 0.3844 \\
\hline 6996321 & 47 & 0 & 0.186 & G:A & 0.409 & 0.0071 & 0.0344 \\
\hline 307253 & 47 & 0 & 0.114 & $\mathrm{~T}: \mathrm{C}$ & 1.000 & 0.6826 & 0.8270 \\
\hline 2376999 & 48 & 0 & 0.490 & $\mathrm{~T}: \mathrm{C}$ & 0.778 & 0.8981 & 0.9709 \\
\hline 7218729 & 47 & 0 & 0.405 & $\mathrm{G}: \mathrm{C}$ & 0.021 & 0.2366 & 0.4028 \\
\hline 5934996 & 47 & 0 & 0.483 & $\mathrm{~A}: \mathrm{T}$ & 1.000 & 0.4220 & 0.6182 \\
\hline 946252 & 46 & 0 & 0.443 & A:G & 0.033 & 0.0035 & 0.0252 \\
\hline 5979395 & 44 & 0 & 0.104 & $\mathrm{G}: \mathrm{A}$ & 0.359 & 0.0001 & 0.0015 \\
\hline
\end{tabular}


Table 3 (continued)

\begin{tabular}{llllllll}
\hline SNP (rs) & $\begin{array}{l}\text { Informative } \\
\text { trios, } n\end{array}$ & $\begin{array}{l}\text { Mendelian } \\
\text { errors, } n\end{array}$ & $\begin{array}{l}\text { Minor allele } \\
\text { frequency }\end{array}$ & Alleles & $\begin{array}{l}\text { Hardy-Wein- } \\
\text { berg p value }\end{array}$ & $\begin{array}{l}\text { TDT } \\
\text { p value }\end{array}$ & $\begin{array}{l}\text { FDR-corrected } \\
\text { p values }\end{array}$ \\
\hline 6654939 & 48 & 0 & 0.493 & T:C & 0.000 & 0.0047 & 0.0296 \\
6530435 & 47 & 0 & 0.091 & G:A & 0.039 & 0.0000 & 0.0000 \\
17878486 & 48 & 0 & 0.168 & T:C & 0.339 & 1.0000 & 1.0000 \\
17149007 & 46 & 1 & 0.306 & C:T & 0.655 & 0.3952 & 0.6072 \\
13151614 & 47 & 0 & 0.302 & G:C & 0.243 & 0.0403 & 0.1304 \\
17676820 & 46 & 0 & 0.487 & C:T & 0.063 & 0.1552 & 0.3154 \\
3750025 & 48 & 0 & 0.017 & T:C & 1.000 & 0.0414 & 0.1304 \\
2615489 & 46 & 3 & 0.397 & A:G & 0.059 & 0.0633 & 0.1899 \\
2615487 & 48 & 0 & 0.372 & T:C & 0.037 & 0.5787 & 0.7595 \\
\hline
\end{tabular}

$\mathrm{p}$ values were corrected using the false discovery rate (FDR). Values in italics show statistically significant differences $(\mathrm{p}<0.05)$.

diagnosed with severe MIH (when the child had at least one tooth with structural loss).

Table 3 shows the results of the TDT analysis. The distribution of SNP genotypes followed the Hardy-Weinberg equilibrium. We found significant results for SNPs rs7821494 (FAM83H gene, $\mathrm{p}=0.00004, \mathrm{OR}=3.7 ; 95 \%$ $\mathrm{CI}=1.75-7.78), \mathrm{rs} 34367704(A M B N$ gene, $\mathrm{p}=0.0457$, $\mathrm{OR}=2.7 ; 95 \% \mathrm{CI}=1.16-6.58), \mathrm{rs} 3789334$ (BMP2 gene, $\mathrm{p}=0.0144, \mathrm{OR}=2.9 ; 95 \% \mathrm{CI}=1.34-6.35), \mathrm{rs} 6099486$ (BMP7 gene, $\mathrm{p}=0.0457, \mathrm{OR}=2.2 ; 95 \% \mathrm{CI}=1.14-4.38)$, rs762642 (BMP4 gene, $\mathrm{p}=0.0075, \mathrm{OR}=2.3 ; 95 \% \mathrm{CI}=$ 1.38-3.65), rs7664896 (ENAM gene, $\mathrm{p}=0.0332$, $\mathrm{OR}=2.1$; $95 \% \mathrm{CI}=1.19-3.51), \mathrm{rs} 1711399(M M P 20$ gene, $\mathrm{p}=0.0136$, $\mathrm{OR}=0.4 ; 95 \% \mathrm{CI}=0.20-0.72)$, rs1711423 (MMP20 gene, $\mathrm{p}=0.0344, \mathrm{OR}=2.1 ; 95 \% \mathrm{CI}=1.18-3.61), \mathrm{rs} 2278163(D L X 3$ gene, $\mathrm{p}=0.0252, \mathrm{OR}=2.8 ; 95 \% \mathrm{CI}=1.26-6.41), \mathrm{rs} 6996321$ (FGFR1 gene, $\mathrm{p}=0.0344, \mathrm{OR}=2.7 ; 95 \% \mathrm{CI}=1.20-5.88$ ), and rs5979395 (AMELX gene, $\mathrm{p}=0.0015, \mathrm{OR}=11.7 ; 95 \%$ $\mathrm{CI}=1.63-84.74)$. Regarding rs5979395, we observed that $97 \%$ of $\mathrm{rs} 5979395^{*} \mathrm{G}$ alleles were transmitted to $\mathrm{MIH}$-affected individuals, whereas only $3 \%$ of rs $5979395^{*} \mathrm{~A}$ alleles were transmitted to unaffected individuals.

\section{Discussion}

This is the first family-based association study conducted regarding MIH. In summary, family-based association designs aimed to avoid the potential confounding effects of population stratification by using the parents or unaffected siblings as the controls for the case patients. The statistical considerations for family-based studies differ from those of population-based investigations. Individuals within the same family are likely to be more similar to one another than are individuals from different families. This phenomenon is referred to in statistics as clustering and implies a within-family correlation. The idea is that there is something unmeasurable (latent), such as diet or underlying biological make-up, that makes people from the same family more alike than people across families. As a result, the trait under investigation is more highly correlated among individuals within the same family. Accounting for the potential within-cluster correlation in the statistical analysis of family-based data is essential to making valid inferences in these settings [Foulkes, 2009].

Genetic associations between SNP rs3790506 (TUFT1) and SNP rs946252 (AMELX) and MIH have previously been investigated by our group using a population-based association design [Jeremias et al., 2013b], but we did not find an association between these SNPs and MIH. Since those SNPs reside in important genes related to amelogenesis [Simmer and Hu, 2001; Deutsch et al., 2002; Stephanopoulos et al., 2005], we evaluated them again in this present study, enrolling a family-based Brazilian sample (391 individuals from 101 nuclear families); however, no significant associations were found. Thereby, we evaluated an additional 63 SNPs in 21 candidate genes related to MIH because they exert some function in any of the presecretory, secretory, transitional, or maturation stages of amelogenesis and because the entire amelogenesis process is under genetic control [Simmer and $\mathrm{Hu}, 2001$ ].

In the following sections, we will discuss our present genetic findings and the rationale for investigating each gene in this study. We found an association between SNP 
rs5979395, in the AMELX (Xq22) gene, and MIH ( $\mathrm{p}=$ 0.006 , OR $=11.7$ ). In addition, $97 \%$ of $\mathrm{MIH}$-affected individuals carry the rs5979395*G allele. Because approximately $5-10 \%$ of all amelogenesis imperfecta cases are Xlinked, it is predictable to find a mutation in the AMELX gene [Bäckman, 1988]. Our study demonstrates that genetic variation in the AMELX gene is associated not only with amelogenesis imperfecta but also with MIH. This gene is fundamental for amelogenesis, which codifies amelogenin, the main protein of dental enamel secreted by ameloblasts during the secretion stage of amelogenesis [Stephanopoulos et al., 2005; Chan et al., 2011].

As ameloblasts differentiate, they deposit in the secretory stage important non-amelogenin enamel matrix proteins, including enamelin (ENAM) and ameloblastin $(A M B N)$, whose genes are located in the long arm of chromosome 4 (4q13) near other genes associated with mineralized tissues, such as osteopontin, bone sialoprotein, bone morphogenetic protein 3, and dentin sialophosphoprotein (4q22) [MacDougall et al., 1997]. Here, the TDT analysis showed a significant association with MIH of the SNPs in the ENAM (rs7664896) and AMBN (rs34367704). Interestingly, $A M B N$ is also expressed in the maturation stage [Winter and Brook, 1975], but other important genes such as amelotin (AMTN, 4q13), which is specifically expressed in maturation-stage ameloblasts [Iwasaki et al., 2005], was not associated with MIH in this study. Tuftelin (TUFT1, 1q21) has been suggested to play an important role during enamel development and mineralization [Deutsch et al., 2002]. Kallikrein-related peptidase $4(K L K 4,19 q 13)$ is produced during the maturation stage to further process the remaining organic matrix [Simmer and $\mathrm{Hu}, 2001$ ]. Moreover, we decided to include in this comprehensive genetic analysis genes encoding bone morphogenetic proteins, such as BMP2 (20p12), BMP4 (14q22), and BMP7 (20q13), because they are expressed in the pre-ameloblasts and ameloblasts (http://honeybee.helsinki.fi/toothexp). We found an association between MIH and SNP rs3789334 in the $B M P 2$, SNP rs762642 in the BMP4, and SNP rs6099486 in the $B M P 7$ gene. We highlight the BMP4 gene which encodes a protein with a vital regulatory function throughout development in mesoderm induction, tooth development, limb formation, bone induction, and fracture repair [Bakrania et al., 2008]. BMP4 knock-out mice showed decreased mature odontoblast differentiation. The mechanism that explains this finding is that the absence of the $B M P 4$ gene decreases not only the BMP signalling but also the expression of three key transcription factors: Dlx3, Dlx5, and osterix. Distal-less 3 (DLX3, 17q21) is highly expressed in ameloblasts and controls many of the down-

Family-Based Genetic Association for $\mathrm{MIH}$ stream genes involved in amelogenesis, such as ameloblastin and amelogenin [Gluhak-Heinrich et al., 2010]. Here we found that the SNP rs2278163 in the DLX3 gene was associated with MIH. BMP signalling, as well as Dlx3 and amelogenin expression, is also indirectly reduced in the ameloblasts and odontoblasts of BMP4 knock-out mice. This supports a key paracrine or endocrine role of odontoblasts derived from BMP4 postnatally on the proper amelogenesis and formation of the enamel [Gluhak-Heinrich et al., 2010]. Interestingly, our study is the first to identify the association of genetic variations in the BMP4 gene with $\mathrm{MIH}$. A genome-wide association study identified SNP rs 13058467 (located near the SCUBE1 gene) as being associated with MIH [Kühnisch et al., 2014]. Even though that study was underpowered, the authors mentioned that the SCUBE1 gene, normally involved in vascular biology, can directly bind to BMP in the epithelial and mesenchymal regions of the developing tooth [Tu et al., 2008], and SCUBE proteins may negatively regulate BMP activity [Aberg et al., 1997; Helder et al., 1998].

The investigated genes fibroblast growth factor 1 (FGF1, 5q31), fibroblast growth factor receptor 1 (FGFR1, $8 \mathrm{p} 11)$, fibroblast growth factor 2 (FGF2, 4q27), its receptor (FGFR2, 10q26), parathyroid hormone (PTH, 11p15), its receptor (PTHR1,3p21), and the transforming growth factor, $\beta-1$ (TGFB1, 19q13) were also included because they are expressed in the differentiation/secretion stages of the incisor/molar ameloblasts of rodents (http://honeybee.helsinki.fi/toothexp). Considering these genes, the only one associated with MIH was the FGFR1 gene SNP rs6996321. In addition, we utilized a wide range of amelogenesis gene expression data in that site, and we noted that this information is in agreement with the literature because amelogenesis is characterized by a dynamic process occurring in dental tissue development, including cellular, biochemical, genetic, and epigenetic changes [Deutsch et al., 2002; Stephanopoulos et al., 2005; Chan et al., 2011].

The removal of amelogenins during maturation is a critical step in enamel mineralization. During tooth development, proteases, such as the matrix metalloproteinase-20 (MMP20), also named enamelysin (MMP20, 11q22), are secreted by ameloblasts and cleave the enamel proteins. MMP20 is a tooth-specific MMP secreted into the enamel matrix during the secretory and transition stages of enamel development [Turk et al., 2006] and is essential for the formation of a properly hardened enamel layer [Shin et al., 2014]. Demonstrating the genetic association of this gene with MIH, 2 SNPs were found to be associated with this enamel defect (rs 1711399 and rs 1711423). The tissue inhibitor of metalloproteinase 2 (TIMP2, 17q25) is a 
natural inhibitor of the matrix metalloproteinases, a group of peptidases involved in the degradation of the extracellular matrix [Noda et al., 2003]. TIMP2 is also expressed in the secretory stage of molar mouse ameloblasts (http:// honeybee.helsinki.fi/toothexp).

Family with sequence similarity 83 , member $\mathrm{H}$ (FAM83H, 8q24.3) encodes an intracellular protein of unknown function that appears to be associated with the Golgi apparatus or trans-Golgi network [Ding et al., 2009] and is most strongly expressed by pre-ameloblasts [Lee et al., 2009]. Based on its expression pattern, Lee et al. [2009] suggested that FAM83H may be involved in the differentiation of pre-ameloblasts into functional ameloblasts and in enamel matrix calcification. The FAM83H protein is required for proper dental enamel calcification [Kim et al., 2008]. Recently, Zhang et al. [2015], showed that FAM83H could influence enamel biomineralization and dentine formation, and they reviewed studies that identified different mutations in the FAM83H gene associated with autosomal dominant hypocalcified amelogenesis imperfecta (ADHCAI) [Zhang et al., 2015]. There are at least 14 different registered mutations in the FAM83H gene associated with ADHCAI (http://omim. org/entry/611927), and Kim et al. [2008] was the first group to observe this. Interestingly, mutations in the FAM $83 \mathrm{H}$ gene are not the only factors that can influence enamel formation. Polymorphisms might have a slight effect on amelogenesis, mainly regarding the enamel mineralization/maturation, because we have demonstrated here the significant association of SNP rs7821494 in the $F A M 83 H$ gene with the genetic predisposition to $\mathrm{MIH}$. Although our results reinforce the evidence regarding the influence of the FAM83H gene on amelogenesis, the mechanisms and functions of the FAM $83 \mathrm{H}$ protein during enamel and dentine formation remain unclear [Zhang et al., 2015].

A potential limitation of our study resides in the accuracy of the diagnosis of the presence/absence of enamel defects, which is more difficult in adult subjects because developmental enamel defects may have been masked by restorations and remineralizing agents. However, the differences found here between MIH-affected patients and unaffected birth family members were significant enough to overcome a potential MIH misdiagnosis. Moreover, the significant genetic factors predisposing subjects to MIH found in this study could be inherent to the population studied. It is necessary to extrapolate these results to other populations because the Brazilian population is an interethnic admixture of Europeans, Africans, and autochthonous Amerindians, thus forming one of the most heterogeneous populations in the world [Alves-Silva et al., 2000]. Obviously, future studies enrolling different ethnic populations affected by MIH should be conducted. Not surprisingly, it is possible that other genes could be identified in different ethnic populations, as observed for other multifactorial diseases, mainly because of the influence of different environmental factors.

Our currents results support the idea that MIH is a multifactorial disturbance [Kuscu et al., 2013] because different genes can influence the occurrence of MIH. However, there is evidence of participating environmental factors [Loli et al., 2015; Oyedele et al., 2015]. These might modify the expression of any genes related to tooth formation at all amelogenesis stages. Moreover, there is substantial evidence supporting the involvement of epigenetic components in defining human phenotypic variations. Epigenetics describe the way in which gene-environment and gene-gene interactions shape a phenotype during development. Currently, epigenetics describe alterations in genomic function, mainly mitotically heritable changes in gene expression, that occur through reversible chemical modifications to the structure of chromatin without altering the DNA sequence [Godfrey et al., 2007].

In conclusion, we showed evidence of the genetic influence on MIH. This result is in agreement with the multifactorial idea of the MIH aetiology, but to prove this, further studies enrolling larger, well-diagnosed and different ethnic populations are necessary to expand the investigation of the genetic and environmental factors as well as the gene-environment interactions that might influence the occurrence of MIH.

\section{Acknowledgements}

This study was supported by FAPESP (São Paulo Research Foundation, Brazil; 2011/13636-5). We are grateful to our patients and their families for their helpful cooperation.

\section{Author Contributions}

Data analysis: F.J., R.S., R.M.S.-C. Study design: F.J., R.S., C.V.M.-M., L.S.-P., R.M.S.-C. Obtained funding: F.J., R.M.S.-C., L.S.-P. Manuscript writing: F.J., R.S., R.M.S.-C. Data collection: F.J., R.A.G.P., M.R., D.G.B., J.F.S., C.M.B.F. DNA manipulation/ genotyping: F.J., M.R., R.S., R.M.S.-C., L.S.F. Revised and reviewed the paper: F.J., R.A.G.P., J.F.S., C.M.B.F., M.R., L.S.F., D.G.B., R.C.L.C., R.S., C.V.M.-M., L.S.-P., R.M.S.-C. 


\section{Disclosure Statement}

\section{References}

Aberg T, Wozney J, Thesleff I: Expression patterns of bone morphogenetic proteins (BMPS) in the developing mouse tooth suggest roles in morphogenesis and cell differentiation. Dev Dyn 1997;210:383-396.

Alaluusua S: Aetiology of molar-incisor hypomineralisation: a systematic review. Eur Arch Paediatr Dent 2010;11:53-58.

Alves-Silva J, da Silva Santos M, Guimarães PE Ferreira AC, Bandelt HJ, Pena SD, Prado VF: The ancestry of Brazilian mtDNA lineages. Am J Hum Genet 2000;67:444-461.

Bäckman B: Amelogenesis imperfecta - clinical manifestations in 51 families in a northern Swedish county. Scand J Dent Res 1988;96: 505-516.

Bakrania P, Efthymiou M, Klein JC, Salt A, Bunyan DJ, Wyatt A, Ponting CP, Martin A, Williams S, Lindley V, Gilmore J, Restori M, Robson AG, Neveu MM, Holder GE, Collin JR, Robinson DO, Farndon P, Johansen-Berg H, Gerrelli D, Ragge NK: Mutations in BMP4 cause eye, brain, and digit developmental anomalies: overlap between the BMP4 and hedgehog signaling pathways. Am J Hum Genet 2008;82:304-319.

Barrett JC, Fry B, Maller J, Daly MJ: Haploview: Analysis and visualization of LD and haplotype maps. Bioinformatics 2005;21:263-265.

Chan HC, Estrella NM, Milkovich RN, Kim JW, Simmer JP, Hu JC: Target gene analyses of 39 amelogenesis imperfecta kindreds. Eur J Oral Sci 2011;119(suppl 1):311-323.

Chen WM, Deng HW: A general and accurate approach for computing the statistical power of the transmission disequilibrium test for complex disease genes. Genet Epidemiol 2001;21: 53-67.

Cho SY, Ki Y, Chu V: Molar incisor hypomineralization in Hong Kong Chinese children. Int J Paediatr Dent 2008;18:348-352.

da Costa-Silva CM, Jeremias F, de Souza JF, Cordeiro Rde C, Santos-Pinto L, Zuanon AC: Molar incisor hypomineralization: prevalence, severity and clinical consequences in Brazilian children. Int J Paediatr Dent. 2010;20:426-434.

Deeley K, Letra A, Rose EK, Brandon CA, Resick JM, Marazita ML, Vieira AR: Possible association of amelogenin to high caries experience in a Guatemalan-Mayan population. Caries Res 2008;42:8-13.

Deutsch D, Leiser Y, Shay B, Fermon E, Taylor A Rosenfeld E, Dafni L, Charuvi K, Cohen Y, Haze A, Fuks A, Mao Z: The human tuftelin gene and the expression of tuftelin in mineralizing and nonmineralizing tissues. Connect Tissue Res 2002;43:425-434.
The authors certify that they have no commercial or associative interests that represent a conflict of interest in connection with this paper.
Ding Y, Estrella MR, Hu YY, Chan HL, Zhang HD, Kim JW, Simmer JP, Hu JC: Fam83h is associated with intracellular vesicles and ADHCAI. J Dent Res 2009;88:991-996.

Dudbridge F: Likelihood-based association analysis for nuclear families and unrelated subjects with missing genotype data. Hum Hered 2008;66:87-98.

Elfrink ME, Ghanim A, Manton DJ, Weerheijm KL: Standardised studies on molar incisor hypomineralisation (MIH) and hypomineralised second primary molars (HSPM): a need. Eur Arch Paediatr Dent 2015;16:247255.

Foulkes AS: Applied Statistical Genetics with R for Population-Based Association Studies. New York, Springer, 2009.

Gluhak-Heinrich J, Guo D, Yang W, Harris MA, Lichtler A, Kream B, Zhang J, Feng JQ, Smith LC, Dechow P, Harris SE: New roles and mechanism of action of BMP4 in postnatal tooth cytodifferentiation. Bone 2010;46: 1533-1545.

Godfrey KM, Lillycrop KA, Burdge GC, Gluckman PD, Hanson MA: Epigenetic mechanisms and the mismatch concept of the developmental origins of health and disease. Pediatr Res 2007;61:5R-10R.

He P, Zhang Y, Kim SO, Radlanski RJ, Butcher K, Schneider RA, DenBesten PK: Ameloblast differentiation in the human developing tooth: effects of extracellular matrices. Matrix Biol 2010;29:411-419.

Helder MN, Karg H, Bervoets TJ, Vukicevic S, Burger EH, D'Souza RN, Wöltgens $\mathrm{JH}$, Karsenty G, Bronckers AL: Bone morphogenetic protein-7 (osteogenic protein-1, OP-1) and tooth development. J Dent Res 1998;77: 545-554.

Iwasaki K, Bajenova E, Somogyi-Ganss E, Miller M, Nguyen V, Nourkeyhani H, Gao Y, Wendel M, Ganss B: Amelotin - a novel secreted, ameloblast-specific protein. J Dent Res 2005; 84:1127-1132.

Jan J, Sovcikova E, Kocan A, Wsolova L, Trnovec T: Developmental dental defects in children exposed to PCBS in eastern Slovakia. Chemosphere 2007;67:S350-S354.

Jeremias F, de Souza JF, Silva CM, Cordeiro Rde C, Zuanon AC, Santos-Pinto L: Dental caries experience and molar-incisor hypomineralization. Acta Odontol Scand 2013a; 71:870-876.
Jeremias F, Koruyucu M, Küchler EC, Bayram M, Tuna EB, Deeley K, Pierri RA, Souza JF, Fragelli CM, Paschoal MA, Gencay K, Seymen F, Caminaga RM, Santos-Pinto L, Vieira AR: Genes expressed in dental enamel development are associated with molar-incisor hypomineralization. Arch Oral Biol 2013b;58: 1434-1442.

Kim JW, Lee SK, Lee ZH, Park JC, Lee KE, Lee MH, Park JT, Seo BM, Hu JC, Simmer JP: FAM83H mutations in families with autosomal-dominant hypocalcified amelogenesis imperfecta. Am J Hum Genet 2008;82:489494

Kühnisch J, Thiering E, Heitmüller D, Tiesler CM, Grallert H, Heinrich-Weltzien R, Hickel R, Heinrich J, Group G-PS, Group L-PS: Genome-wide association study (GWAS) for molar-incisor hypomineralization (MIH). Clin Oral Investig 2014;18:677-682.

Kuscu OO, Sandalli N, Dikmen S, Ersoy O, Tatar I, Turkmen I, Caglar E: Association of amoxicillin use and molar incisor hypomineralization in piglets: visual and mineral density evaluation. Arch Oral Biol 2013;58:14221433.

Lacruz RS, Smith CE, Moffatt P, Chang EH, Bromage TG, Bringas $P$, Nanci A, Baniwal SK, Zabner J, Welsh MJ, Kurtz I, Paine ML: Requirements for ion and solute transport, and $\mathrm{pH}$ regulation during enamel maturation. J Cell Physiol 2012;227:1776-1785.

Lee MJ, Lee SK, Lee KE, Kang HY, Jung HS, Kim JW: Expression patterns of the Fam83h gene during murine tooth development. Arch Oral Biol 2009;54:846-850.

Loli D, Costacurta M, Maturo P, Docimo: Correlation between aerosol therapy in early childhood and molar incisor hypomineralisation. Eur J Paediatr Dent 2015;16:73-77.

MacDougall M, DuPont BR, Simmons D, Reus B, Krebsbach P, Kärrman C, Holmgren G, Leach RJ, Forsman K: Ameloblastin gene (AMBN) maps within the critical region for autosomal dominant amelogenesis imperfecta at chromosome 4q21. Genomics 1997;41:115-118.

Muratbegovic A, Markovic N, Ganibegovic Selimovic M. Molar incisor hypomineralisation in Bosnia and Herzegovina: aetiology and clinical consequences in medium caries activity population. Eur Arch Paediatr Dent 2007; 8:189-194.

Noda K, Ishida S, Inoue M, Obata K, Oguchi Y, Okada Y, Ikeda E. Production and activation of matrix metalloproteinase-2 in proliferative diabetic retinopathy. Invest Ophthalmol Vis Sci 2003;44:2163-2170. 
O'Connell JR, Weeks DE: PedCheck: a program for identification of genotype incompatibilities in linkage analysis. Am J Hum Genet 1998;63:259-266.

Oyedele TA, Folayan MO, Adekoya-Sofowora CA, Oziegbe EO, Esan TA: Prevalence, pattern and severity of molar incisor hypomineralisation in 8- to 10-year-old school children in Ile-Ife, Nigeria. Eur Arch Paediatr Dent 2015; 16:277-282.

Secolin R, Rocha CS, Torres FR, Santos ML, Maurer-Morelli CV, Santos NF, Lopes-Cendes I: LINKGEN: a new algorithm to process data in genetic linkage studies. Genomics 2008;91: 544-547.

Shimizu T, Ho B, Deeley K, Briseño-Ruiz J, Faraco IM, Schupack BI, Brancher JA, Pecharki GD, Küchler EC, Tannure PN, Lips A, Vieira TC, Patir A, Yildirim M, Poletta FA, Mereb JC, Resick JM, Brandon CA, Orioli IM, Castilla EE, Marazita ML, Seymen F, Costa MC, Granjeiro JM, Trevilatto PC, Vieira AR: Enamel formation genes influence enamel microhardness before and after cariogenic challenge. PLoS One 2012; 7:e45022.

Shin M, Hu Y, Tye CE, Guan X, Deagle CC, Antone JV, Smith CE, Simmer JP, Bartlett JD: Matrix metalloproteinase-20 over-expression is detrimental to enamel development: a Mus musculus model. PLoS One 2014;9:e86774.
Simmer JP, Hu JC: Dental enamel formation and its impact on clinical dentistry. J Dent Educ 2001;65:896-905

Sönmez H, Yıldırım G, Bezgin T: Putative factors associated with molar incisor hypomineralisation: an epidemiological study. Eur Arch Paediatr Dent 2013;14:375-380.

Souza JF, Costa-Silva CM, Jeremias F, Santos-Pinto L, Zuanon AC, Cordeiro RC: Molar incisor hypomineralisation: possible aetiological factors in children from urban and rural areas. Eur Arch Paediatr Dent 2012;13:164-170.

Stephanopoulos G, Garefalaki ME, Lyroudia K: Genes and related proteins involved in amelogenesis imperfecta. J Dent Res 2005;84:11171126.

Tu CF, Yan YT, Wu SY, Djoko B, Tsai MT, Cheng CJ, Yang RB: Domain and functional analysis of a novel platelet-endothelial cell surface protein, SCUBE1. J Biol Chem 2008;283: 12478-12488.

Turk BE, Lee DH, Yamakoshi Y, Klingenhoff A, Reichenberger E, Wright JT, Simmer JP, Komisarof JA, Cantley LC, Bartlett JD: MMP20 is predominately a tooth-specific enzyme with a deep catalytic pocket that hydrolyzes type V collagen. Biochemistry 2006;45:38633874 .
Vieira AR, Marazita ML, Goldstein-McHenry T: Genome-wide scan finds suggestive caries loci. J Dent Res 2008;87:435-439.

Weerheijm KL, Duggal M, Mejàre I, Papagiannoulis L, Koch G, Martens LC, Hallonsten AL: Judgement criteria for molar incisor hypomineralisation (MIH) in epidemiologic studies: a summary of the European meeting on MIH held in Athens, 2003. Eur J Paediatr Dent 2003;4:110-113.

Weerheijm KL, Jälevik B, Alaluusua S: Molar-incisor hypomineralisation. Caries Res 2001;35: 390-391.

Winter GB, Brook AH: Enamel hypoplasia and anomalies of the enamel. Dent Clin North Am 1975;19:3-24.

Wright JT, Carrion IA, Morris C: The molecular basis of hereditary enamel defects in humans. J Dent Res 2015;94:52-61.

Wuollet E, Laisi S, Salmela E, Ess A, Alaluusua S: Background factors of molar-incisor hypomineralization in a group of Finnish children. Acta Odontol Scand 2014;72:963-969.

Zhang C, Song Y, Bian Z: Ultrastructural analysis of the teeth affected by amelogenesis imperfecta resulting from FAM83H mutations and review of the literature. Oral Surg Oral Med Oral Pathol Oral Radiol 2015;119:e69-e76. 